\title{
Is the National Study of Learning Mindsets Nationally-Representative?
}

\author{
Maithreyi Gopalan ${ }^{1}$ and Elizabeth Tipton ${ }^{2}$
}

November 3, 2018

\begin{abstract}
The National Study of Learning Mindsets (NSLM) is a randomized trial evaluating an intervention in a national sample of schools that were selected to participate via probability sampling methods. The response rate for this study was $56 \%$. This paper evaluates whether site-level non-response compromises the generalizability of the results from the achieved sample of schools in the NSLM. Comparisons of characteristics of schools taking part in the NSLM relative to national benchmarks shows that the NSLM sample has a high degree of similarity to the population of all regular, U.S. public high schools with at least 25 students in $9^{\text {th }}$ grade and in which $9^{\text {th }}$ grade is the lowest grade, via two metrics. First, comparisons of school- and districtlevel characteristics between the NSLM and the national population of inference show few statistically significant differences. Second, applying an empirical method to quantify the degree of generalizability - the Tipton (2014) generalizability index-found that the analytic sample is generalizable to the population overall (generalizability index $=.98$ on a 0 to 1 scale) and to four other theoretically-relevant inference populations identified based on school achievement level and school minority concentration measures (generalizability indices $>.93$ ). Thus, full-sample estimates and conditional estimates (within school achievement and racial composition subgroups) are likely to be highly generalizable to the corresponding populations of inference.
\end{abstract}

\footnotetext{
${ }^{1}$ The Pennsylvania State University; Corresponding Author Email: smg632@psu.edu; ${ }^{2}$ Elizabeth Tipton; Northwestern University, Institute of Policy Research; Email: tipton@northwestern.edu. We thank David Yeager for sharing the primary list of schools included in the NSLM and the national school sampling frame from which the analytic sample for the NSLM was drawn. We also thank David Yeager and Paul Hanselman for their feedback on earlier drafts of this paper. Remaining errors are our own. This manuscript uses the list of schools included in the National Mindset Study (PI: D. Yeager; Co-ls: R. Crosnoe, C. Dweck, C. Muller, B. Schneider, \& G. Walton), which was made possible through methods and data systems created by the Project for Education Research That Scales (PERTS), data collection carried out by ICF International and led by Kate Flint, Alice Roberts, Jill Trott, and Ronaldo lachan, meetings hosted by the Mindset Scholars Network at the Center for Advanced Study in the Behavioral Sciences, assistance from C. Hulleman, R. Ferguson, M. Shankar, T. Brock, C. Romero, D. Paunesku, C. Macrander, T. Wilson, E. Konar, M. Weiss, E. Tipton, and A. Duckworth, and funding from the Raikes Foundation, the William T. Grant Foundation, the Spencer Foundation, the Bezos Family Foundation, the Character Lab, the Houston Endowment, Angela Duckworth (personal gift), and the President and Dean of Humanities and Social Sciences at Stanford University. These data were made available to the researchers through the Population Research Center at The University of Texas at Austin which is supported by grant, P2CHD042849, awarded by the Eunice Kennedy Shriver National Institute of Health and Child Development. Opinions reflect those of the authors and do not necessarily reflect those of the granting agencies.
} 


\section{Introduction}

The National Study of Learning Mindsets (NSLM) was a person-level random assignment, double-blind, randomized control trial (RCT) aimed at testing the effectiveness of a growth mindset intervention-an intervention that taught that intellectual abilities are not fixed but can be developed (see an overview in Yeager et al., 2016, which reports the pilot for the NSLM). The goal for the study was to estimate the average treatment effect of this intervention and understand heterogeneity in the effect across students, classrooms, and schools in the population of all regular, U.S. public high schools with at least 25 students in $9^{\text {th }}$ grade and in which $9^{\text {th }}$ grade is the lowest grade. Initially, 139 high schools were selected for recruitment into the study using a stratified probability sampling method (see Tipton, Yeager, lachan, \& Schneider, in press for additional detailed about the stratified probability sampling method used). Of these 139 high school schools, 76 agreed and participated in the NSLM. These 76 high schools are referred to as the analytic sample throughout this paper. Within each of these high schools, a near-census of all $9^{\text {th }}$-graders (or, in some schools, a very high proportion of a random sample of $9^{\text {th }}$ graders) were randomly assigned to either the treatment arm or a control group. The activities lasted approximately 50 minutes total.

In this paper, we ask: how generalizable is the analytic sample of schools included in the NSLM to the inference population? We ask this question since not all schools selected agreed to take part - what is called "non-response" in survey sampling or a "refusal" in experimental generalization.

Specifically, we compare the analytic sample to the inference population on a variety of observable school- and district-level covariates. We summarize these comparisons with an overall degree of similarity - the generalizability index (Tipton, 2014). We find that the analytic sample is highly similar to the inference population when compared using a large set of covariates. We also find that the analytic sample is highly similar to other inference populations of interest (school subgroups) thus enabling "narrow to broad generalizations" (Shadish, Cook, \& Campbell, 2002).

\section{Generalizability and External Validity}

The causal inference literature spanning across applied disciplines-such as economics, psychology, and program evaluation-has focused predominantly on estimating internally valid treatment effects. Traditionally, internal validity concerns have rested on testing assumptions of individual-level selection bias-whether those who received/were assigned the treatment are comparable on observed as well as unobserved characteristics to those who did not receive the treatment. Such focus on self-selection bias, may have, indeed, led to the growth of quasi-experimental research designs and the widespread use of RCTs in the treatment effect literature (Angrist \& 
Pischke, 2010; Morgan \& Winship, 2007). ${ }^{1}$

Only recently have scholars begun paying more attention to "site-selection bias"(Allcott, 2015; Olsen, Orr, Bell, \& Stuart, 2013; Tipton \& Olsen, 2018). For example, Alcott (2015) show that site-level characteristics may be correlated with observed treatment effects even in well-conducted multisite RCTs (implemented with high-fidelity) in the absence of randomly-selected evaluation sites. Formally, Alcott (2015) call this the "external unconfoundedness" assumption, which requires that "sample sites are as good as randomly selected from the population of target sites". Similarly, Olsen et al. (2013), recommend that researchers evaluating interventions focus on both internalarising from internal validity concerns such as self-selection, spillovers, and attrition-as well as external validity concerns-such as lack of generalizability between the experimental sample and relevant population of inference.

There is also a robust literature on evaluating the representativeness of samples in the survey research literature (Holbrook, Krosnick, \& Pfent, 2007; Maclnnis, Krosnick, Ho, \& Cho, In Press; Yeager et al., 2011). A key finding from the literature is the high-level of accuracy and generalizability of results achieved from well-conducted probability samples even with low response rates. Additionally, they find that large and heterogeneous samples, on the other hand, are less-representative of national inference populations, regardless of response rates. While that line of research has proceeded independent of the experimental literature because of its focus on point estimates, like the proportion of a population espousing a given attitude, rather than on causal effects, there is converging evidence from that literature for the use of probability sampling method in site selection.

This paper employs recent methods to assess the justifiability of making the "external unconfoundedness" assumption, thereby addressing a key concern regarding external validity in multisite RCTs. Specifically, this analysis seeks to understand if site-selection bias in NSLM is ignorable overall as well as with respect to potential treatment effect moderators-such as school- and district-level demographic characteristics related to school resources, educational attainment, and school resources related to the quality of instruction (Tipton et al., in press).In other words, this paper's central question is: Does the final analytic sample of schools included in the NSLM as good as a random selection from the inference population of all high schools in the US?

The choice of site-level covariates used to evaluate the justifiability of making the "external unconfoundedness" assumption in the NSLM is driven by theoretical considerations of hypothesized site-level moderators of treatment effects in the NSLM,

\footnotetext{
${ }^{1}$ Indeed, classic introductory texts on causal inference essentially gloss over the external validity concern when setting up the assumptions for generating an average treatment effect (ATE) by assuming "random" selection of sites. While economists have raised concerns about potential site-selection issues in the past, rigorous empirical work testing these issues remain scarce. For example, concerns about the treatment effects in the evaluation of Job Training Partnership Act of 1982 (JTPA) — which included an evaluation of the job training programs in only 16 sites that agreed to participate from the original 200 job training sites invited-was questioned (Heckman, 1992). However, while larger multisite RCTs have since proliferated the causal inference literature, to the best of my knowledge, I am not aware of any multisite RCT that has carried out an in-depth probability-based site-selection process from a known inference population, especially in education, as done so by the NSLM so far.
} 
past empirical research on variation in school- and district-level characteristics across the US, and data availability. While the chosen site-level covariates for comparison is by no means exhaustive, the list captures most of the observable characteristics available at the school- and district-level that are predicted, given available theory, to be plausibly related to effect size moderation (Tipton, 2014). For example, the site-level covariates chosen in this analysis-such as racial composition, socioeconomic composition, gender composition, special education and English learner classifications-include most of the school- and district-level moderators used in past educational research. However, the generalizability and external validity of internal-valid treatment effects from the NSLM may still be affected by other, unobserved site-level characteristics that may be correlated with the treatment effects.

\section{Data and Measures}

Population. This paper analyses data based on the list of high schools included in the analytic sample in the NSLM study and the originally defined inference population. The inference population was based on a school sampling frame constructed from comprehensive data sources such as the Common Core of Data (CCD) (National Center for Education Statistics, 2018a) provided by the National Center for Educational Statistics (NCES) and Market Data Retrieval (MDR) (Dun \& Bradstreet, 2018), and included all regular public schools in the US that served grades 9-12 with at least $259^{\text {th }}$. grade students. The school sampling frame construction, design, and subsequent probability sampling design for site selection followed standard best practices used by other nationally-representative surveys conducted for the Center for Disease Control such as the 2014 School Health Policies and Practices Study (SHPPS).

Specifically, the following exclusions were made from the national sample of high schools to create the final school sampling frame. All non-public schools (such as private and catholic schools), charter schools, schools run by Bureau of Indian Affairs or the Department of Defense, and other special schools such as schools for the deaf or blind, alternative schools, and adult education institutions were excluded. Magnet schools, early college high schools, or schools with special emphases, however, were included. Then, schools with enrollment of less than $259^{\text {th }}$ grade students were also excluded from the sampling frame because an RCT in such a school was expected to yield estimates that are too imprecise. In all, there were 11,221 high schools in the sampling frame-hereafter, referred to as inference population. Questions and analyses of generalizability carried out in this paper is primarily concerned with generalization to this population of interest.

Sample. Of the schools in the population frame, 139 were randomly selected (without replacement) based on a 2-stage stratified design with probability proportional to size. A professional research firm with expertise in conducting nationally-representative schoolbased studies executed extensive recruitment efforts for all 139 schools, including mailings, calls, and site visits. Overall, 76 schools were successfully recruited to participate in the NSLM and are included in the analytic sample. 
Data frame. To make comparisons between the analytic sample and population, we developed a data frame that met the inclusion criteria for the inference population. This frame was developed from the Common Core of Data (CCD). We were able to identify most of the schools ${ }^{2}$ in the CCD. The CCD provides enrollment figures by grade, race/ethnicity, gender, and socioeconomic status (free/reduced-price lunch status figures) for all schools in the US. We focus on the 2015-16 academic year since this was the year the NSLM study was conducted. Using the NCES-provided school identifier, we merge the school-level covariates provided by the CCD to our samples.

Additionally, I merged the above dataset with the AY 2015-16 school-level data provided by the Office of Civil Rights (OCR) (U.S. Department of Education, Office for Civil Rights, 2018). The OCR provides school-level information on a variety of covariates including high school course-taking and chronic absenteeism for all schools in the US. While the OCR is the only national data that provides certain school-level information such as those mentioned above, there have been some criticisms of the data quality from OCR. First, the OCR does not provide disaggregated enrollment data by grade and race/ethnicity for schools. Most estimates are aggregated at the schoollevel. Second, there have been recent media reports questioning the veracity of certain indicators included in the OCR such as the number of shootings in a school (Kamentz, 2018) raising concerns about the overall quality of data collected and reported by the OCR. Despite these data limitations, aggregate high school course-taking rates and chronic absenteeism rates have not received the same kinds of criticism and so they are useful benchmarks and are thus included in this paper. Further information on these measures is included in the Appendix.

Finally, I merged the above dataset with a set of district-level demographic variables provided by the Stanford Education Data Archive (Reardon, Shear, Fahle, Kalogrides, \& DiSalvo, 2017) These covariates are curated from the 2006-2010 School District Demographics System (SDDS). SDDS is a special school district-level tabulation of American Community Survey (ACS) data (National Center for Education Statistics, 2018b). It includes tabulations of demographic and socioeconomic characteristics of families who live in each school district in the U.S. and who have children enrolled in public schools. Thus, it provides detailed data on the family characteristics of children enrolled in each school district. Note that we use the 2006-2010 ACS data because only these years provide tabulations separately for parents of children enrolled in public schools. Please see Table 5 for the complete listing of various school- and district-level measures included in the analysis along with their original data source. All these data sources are publicly-available. To make the comparisons apples-to-apples all data on the analytic sample and the various inference populations come from the same official sources. I do not aggregate student-level data from the NSLM.

\footnotetext{
2256 schools from the sampling frame, of which seven schools are also in the analytic sample, were not matched with the AY 2015-16 CCD data. Errors in school identifiers, mergers of schools, untimely or poor-quality data submission to CCD by the schools may result in such mismatches.
} 
Subgroups. In addition to comparing the analytic sample and the inference population, I also include corresponding comparisons for four theoretically-relevant subgroups of schools. These subgroups of schools were identified based on two hypothesized school-level moderators of treatment effects in the NSLM-school achievement and school minority concentration. The school achievement measure was created using a latent variable model measuring school achievement on a range of achievement metrics. In all, the schools in the population of inference were categorized into two groups based on their school achievement ratings-schools that fell in the bottom $75 \%$ of the school achievement latent measure, and schools that fell in the top $25 \%$ of the school achievement latent measure (see Tipton, Yeager, lachan, \& Schneider, In Press for more details about the school achievement model). The school minority concentration measure includes the proportion of African American and Hispanic students in the school. Schools at or above the population median rates of school minority concentration were identified as belonging to the "high" minority concentration category; and schools with lower than median rates of school minority concentration were classified as "low" on the school minority concentration measure. These school subgroups were identified for the entire national school sampling frame and used in the stratified sampling method used to create the analytic sample for the NSLM study. Therefore, we can identify the following four groups of schools in the analytic sample as well as the national population of inference:

(1) Schools falling in the bottom $75 \%$ of the school achievement metric

(2) Schools falling in the top $25 \%$ of the school achievement metric

(3) Schools with low minority concentration

(4) Schools with high minority concentration

(1) and (2), and (3) and (4) are mutually exclusive and exhaustive, respectively.

These additional subgroup comparisons are explored to understand if the analytic sample is representative of multiple inference populations. These comparisons are also relevant when exploring in-depth the external validity of the average as well as heterogenous treatment effects of the growth mindset intervention evaluated in the NSLM. We do not show these subgroup comparisons for the district-level analyses because these subgroups are defined at the school level and schools vary on these dimensions within districts.

\section{Methods}

This paper employs three analytical approaches-univariate comparisons between the analytic sample and inference populations using school-level benchmarks, univariate comparisons between analytic sample and inference populations with school-districtlevel benchmarks, and a multivariate sampling propensity score model-based generalizability index calculation. First, descriptive statistics of various school-level covariates that are available from the CCD, and that have been identified as important 
for generalization-such as total enrollment, racial composition of the students, gender, and socioeconomic composition of $9^{\text {th }}$-grade students are provided for the analytic sample and the national population of inference. Additionally, comparisons of other relevant school-level benchmarks-such as enrollment rates in gateway classes like Algebra 1 and Algebra 2, Advance Placement (AP) classes, passing rates in AP exams, and chronic absenteeism rates are also provided. For the analytic sample, both weighted and unweighted means are included for comparisons with the inference population. In the weighted analysis, school-level post-stratification weights, which includes adjustments for unequal probability of selection and non-response, are included. Comparisons include descriptive statistics comprising of standardized mean differences between the analytic sample means with the national inference population means.

Past research on educational disparities shows that there is enormous variation in a range of demographics - such as racial and socioeconomic composition factors-not just across schools but also across higher aggregates such as school districts in the US (Reardon et al., 2017). Also, most school finance and budgeting decisions are made at the school district-level rather than at the school-level. To understand if the school districts to which the schools in the analytic sample belong are representative of a national sample of high-school districts, comparisons between the analytic sample and the national population of inference on a range of district-level covariates are also provided. Weights are excluded from this analysis as site-selection was not carried out at the district-level of analysis in the NSLM. Similar descriptive statistics (mean and standard deviation) of various district-level covariates and mean-comparisons between the districts included in the analytic sample and the inference populations are provided. The district-level covariates included in this analysis are curated from the OCR and ACS—such as racial composition of students in the district (\%African American, $\%$ Hispanic, \%Asian, \%White); socioeconomic composition (\%Free and reduced-price lunch); information on English language learners (ELL), special education students, average per-pupil expenditures, and average socioeconomic conditions of households in the district using factors-such as percentage of adults with BA degree, percentage of households that received food stamps or SNAP benefits, teen fertility rates, and others.

Finally, this paper calculates the generalizability index (Tipton, 2014)—a summary measure - to provide the degree of similarity between the sample of schools in the analytic sample and the inference population. Following Tipton (2014), I calculate the generalizability index using a sampling propensity score such that

$$
S(X)=\operatorname{Pr}(Z=1 \mid X)
$$

Where $Z$ is a binary indicator with a value of 1 if the unit is in the analytic sample $S$ and 0 if the unit is not in the analytic sample, but in the inference population, $P$, and $X$ is a vector of school-level covariates. This sampling propensity score can be thought of as a balancing score, and is estimated using a simple logistic regression model shown below 


$$
\log \left[\frac{S(X)}{(1-S(X))}\right]=\alpha_{0}+\alpha_{1} X_{1}+\cdots+\alpha_{m} X_{m}
$$

Having defined the sampling propensity score $S(X)$ for a set of covariates $X$, we calculate the generalizability index

$$
\beta=\int \sqrt{f_{s}(s) f_{p}(s)} d s
$$

where $f_{s}(s)$ and $f_{p}(s)$ are the distributions of logits (predicted values from the logistic regression models defined earlier) in the analytic sample and the inference population, respectively. This index takes on a value between 0 and 1 where a value of 0 means that the analytic sample $S$ and inference population $P$ are completely different and a value of 1 indicating the sample is an exact miniature of the population on the selected covariates (i.e., all SMDs for the covariates are 0). I estimate this index using kernel densities and the $\mathrm{R}$ code provided by Tipton (2014) in the online supplement. The code is reproduced in the appendix for reference as well.

\section{Results and Discussion}

Tables 1 focuses on school-level characteristics. The first panel (see columns 1-5) and second panel (see columns 6-10) include descriptive statistics of the analytic sample and the national school sampling frame, respectively. The first column in each panel provides the means of the various school-level characteristics for the full analytic sample and sampling frame, respectively. Columns 2-5 provide means within the theoretically-relevant subgroups of schools defined earlier based on school quality and school minority concentration. The third panel (see columns 11-15) includes the corresponding comparisons of the mean characteristics between the analytic sample and the sampling frame for the full sample as well as the subgroups. We provide standardized mean differences (SMD) for all non-proportion-based covariates and absolute differences for proportion-based covariates in the last panel.

Table 1 reveals that (1) in the full sample, none of the differences are meaningfully different between the analytic sample and the sampling frame; and (2) of the eight school-grade-level demographic comparisons, only one (total enrollment) shows absolute SMD greater than 0.25 in one subgroup comparison. It has also been shown that rule of thumb estimate of 0.25 to judge differences in absolute SMDs, might be conservative when assessing generalizability (Tipton, Hallberg, Hedges, \& Chan, 2017). See appendix for additional comparisons. Together, these tables show that the analytic sample and the sampling frame are similar with respect to race, gender, socioeconomic composition, school size, and several other high-school course-taking benchmarks at the school-level. We observe similar patterns for the subgroups as well showing that the analytic sample and the sampling frame are comparable for low-achieving and highachieving public high schools, as well as with respect to schools with low and high 
minority concentration in the US. Finally, the combined generalizability index, when all the above benchmarks are included in the sampling propensity score model, is .93.

Table 3 provides the mean and standard deviations of district-level characteristics curated from the CCD and ACS. Again, across 17 different district-level covariates, we observe virtually no difference between the analytic sample and sampling frame. A notable exception are the school district size measures. The school districts in the analytic sample are larger in size, owing to the high number of rural schools in the NSLM. Additionally, in the appendix, comparisons of other district-level benchmarks (see Table A3) that have been used in the past to assess the generalizability of 11 large-scale education evaluations is shown. These large-scale evaluations include randomized control trials or regression discontinuity studies conducted by the National Center for Education Evaluation and Regional Assistance (NCEE) and described by Stuart, Bell, Ebnesajjad, Olsen, \& Orr (2017). Again, we find similar results of nonsignificant differences when comparing the NSLM analytic sample with the national inference population on the district-level benchmarks used by Stuart et al., (2017); while the school districts in the analytical sample are larger; we find that the absolute SMDs of the NSLM analytic sample are considerably smaller for all benchmarks than those reported for the 11 large-scale educational evaluations. More importantly, the combined generalizability index for those benchmarks are also high at .93.

Finally, Table 4 provides information on the degree of similarity between the analytic sample and the national inference population based on our preferred sampling propensity score model specification. The vector of school-level covariates included in our preferred specification were chosen based on two considerations (1) prior empirical evidence suggesting variation in these covariates across the units of analyses i.e. schools in this experiment; and (2) theoretical consideration suggesting these covariates may explain variation in treatment effects across sites in the NSLM. These include:

- School size (Total enrollment)

- Racial composition of students in the school (\%White; \%African American, $\%$ Hispanic)

- Socioeconomic composition of students in the school (\% Free or reduced-price lunch recipients)

- Gender composition of students in the school (\% Female)

- Percentage of Special Education Students in the district (all schools within the district get the same value because reliable school-level estimate of this measure is not readily available)

- Percentage of English Language Learner Students in the district (all schools with the district get the same value because reliable school-level estimate of this measure is not readily available)

The above parsimonious set of benchmarks included in the sampling propensity score model were chosen from the exhaustive set of benchmarks shown earlier based on 
empirical and theoretical considerations regarding treatment heterogeneity, described earlier, as well as to minimize missing values. For example, when a larger number of school- or district-level covariates are included, schools (districts) that have one of more of these benchmark values as missing are dropped from the analysis and not included in the generalizability index calculations. In all, the generalizability index, described below, should be interpreted as being conditional on the above benchmarks.

The generalizability index for the analytic sample is .98 showing that the NSLM study has "very high"(Tipton, 2014 p. 491) generalizability to the population of all public highschools serving grades 9-12 with at least 25 students in the US. Guidance to interpret the magnitudes of these generalizability indices depends on the analytic sample size as well as the number of covariates included in the sampling propensity score model. The rules of thumb values are based on features of random samples, specifically based on critical values of the sampling distributions derived here under random sampling (see Tipton et al., 2017). Using their guidance, we calculate the rule of thumb values with 8 covariates and 76 sites as .97. In other words, if the estimated generalizability index for the full sample is greater than .97, then the analytic sample is "like" a random sample from the population of interest and has "very high" generalizability, conditional on the benchmarks included in the sampling propensity score model. We find that to be the case for the NSLM analytic sample with a generalizability index of 0.98 . We also find that to be true for the four theoretically-defined subgroups of the NSLM analytic samples as defined earlier. The rules of thumb values for generalizability interpretations for the subgroups are .96, .90,.95, and .93, respectively (see Appendix for further guidance on interpretations). Finally, the generalizability index is also robust (above 0.90 in most cases) to alternative specifications of the sampling propensity score model that includes a larger set of school- and district-level benchmarks (as shown in the earlier tables).

\section{Conclusion}

In this paper, we show that the NSLM is highly generalizable to the national sample of all public high schools with at least 25 students serving grades 9-12. Despite site-level non-response, across a variety of school-and district-level benchmarks, the analytic sample is similar to the national population of inference. Furthermore, the analytic sample is generalizable to four other theoretically-relevant inference populations based on school quality and school minority concentration.

These findings are also in-line with evidence from the survey research literature that shows that in random-digit-dialing (RDD) survey response rates are essentially uncorrelated with survey accuracy (Yeager et al., 2011). Survey methodologists have shown that low response rate does not automatically lead to non-response bias as long as non-response is not systematically correlated with factors/characteristics understudy. As noted, research has shown that survey accuracy is uncorrelated to wide variations in survey response rates (ranging between 5 and 90 percent) (Holbrook et al., 2007; Maclnnis et al., In Press). 
Likewise, with respect to the NSLM, as long as site-level non-response is unrelated to site-level characteristics (that may vary across the population of interest, and/or are hypothesized to moderate the treatment effects across sites), we can expect the internally valid causal effects of the intervention (estimated after accounting for poststratification weights) to be externally valid as well and generalize to the inference population(s) of interest. Together, the various analyses included in this paper provide evidence to support such an interpretation of the NSLM results. 


\section{References}

Allcott, H. (2015). Site Selection Bias in Program Evaluation. The Quarterly Journal of Economics, 130(3), 1117-1165. https://doi.org/10.1093/qje/qjv015

Allcott, H., \& Mullainathan, S. (n.d.). External Validity and Partner Selection Bias. National Bureau of Economic Research, Working Paper(18373).

Angrist, J., \& Pischke, J.-S. (2010). The Credibility Revolution in Empirical Economics: How Better Research Design is Taking the Con out of Econometrics. Journal of Economic Perspectives, 24(2), 3-30. https://doi.org/10.3386/w15794

Dun \& Bradstreet. (2018, September 12). Education data: Find the right educators. Retrieved from https://mdreducation.com/education-database/

Heckman, J. (1992). Randomization and Social Programs. In C. Manski \& I. Garfinkel (Eds.), Evaluating Welfare and Training Programs.

Holbrook, A. L., Krosnick, J. A., \& Pfent, A. (2007). The Causes and Consequences of Response Rates in Surveys by the News Media and Government Contractor Survey Research Firms. In Advances in Telephone Survey Methodology (pp. 499-528). Wiley-Blackwell. https://doi.org/10.1002/9780470173404.ch23

Kamentz, A. (2018). The School Shootings That Weren't. Retrieved October 8, 2018, from https://www.npr.org/sections/ed/2018/08/27/640323347/the-schoolshootings-that-werent

Maclnnis, B., Krosnick, J. A., Ho, A. S., \& Cho, M.-J. (In Press). The Accuracy of Measurements with Probability and Nonprobability Survey Samples: Replication and Extension. Public Opinion Quarterly. 
Morgan, S. L., \& Winship, C. (2007). Counterfactuals and Causal Inference: Methods and Principles for Social Research. Cambridge University Press.

National Center for Education Statistics. (2018a, September 6). Common Core of Data (CCD). Retrieved September 6, 2018, from https://nces.ed.gov/ccd/pubschuniv.asp

National Center for Education Statistics. (2018b, September 12). Education demographics and geographic estimates: American Community Survey (ACS). Retrieved from https://nces.ed.gov/programs/edge/Demographic/ACS

Olsen, R. B., Orr, L. L., Bell, S. H., \& Stuart, E. A. (2013). External Validity in Policy Evaluations That Choose Sites Purposively. Journal of Policy Analysis and Management, 32(1), 107-121. https://doi.org/10.1002/pam.21660

Reardon, S. F., Shear, B., Fahle, E., Kalogrides, D., \& DiSalvo, R. (2017). Stanford Education Data Archive (Version 2.0).

Shadish, W., Cook, T., \& Campbell, D. (2002). Experimental and quasi-experimental designs for generalized causal inference (2nd ed.). Boston: Houghton Mifflin.

Stuart, E. A., Bell, S. H., Ebnesajjad, C., Olsen, R. B., \& Orr, L. L. (2017). Characteristics of School Districts That Participate in Rigorous National Educational Evaluations. Journal of Research on Educational Effectiveness, 10(1), 168-206. https://doi.org/10.1080/19345747.2016.1205160

Tipton, E. (2014). How Generalizable Is Your Experiment? An Index for Comparing Experimental Samples and Populations. Journal of Educational and Behavioral Statistics, 39(6), 478-501. 
Tipton, E., Hallberg, K., Hedges, L. V., \& Chan, W. (2017). Implications of Small Samples for Generalization: Adjustments and Rules of Thumb. Evaluation Review, 41(5), 472-505. https://doi.org/10.1177/0193841X16655665

Tipton, E., \& Olsen, R. B. (2018). A Review of Statistical Methods for Generalizing From Evaluations of Educational Interventions. Educational Researcher, 0013189X1878152. https://doi.org/10.3102/0013189X18781522

Tipton, E., Yeager, D., lachan, R., \& Schneider, B. (in press). Designing Probability Samples to Study Treatment Effect Heterogeneity. In P. . Lavrakas (Ed.), Experimental methods in survey research: Techniques that combine random sampling with random assignment. New York, NY: Wiley.

U.S. Department of Education, Office for Civil Rights. (2018, September 6). CDRC: Civil Rights Data Collection. Retrieved September 6, 2018, from https://ocrdata.ed.gov/

Yeager, D. S., Krosnick, J. A., Chang, L., Javitz, H. S., Levendusky, M. S., Simpser, A., \& Wang, R. (2011). Comparing the Accuracy of RDD Telephone Surveys and Internet Surveys Conducted with Probability and Non-Probability Samples. Public Opinion Quarterly, 75(4), 709-747. https://doi.org/10.1093/poq/nfr020

Yeager, D. S., Romero, C., Paunesku, D., Hulleman, C. S., Schneider, B., Hinojosa, C., ... Dweck, C. S. (2016). Using design thinking to improve psychological interventions: The case of the growth mindset during the transition to high school. Journal of Educational Psychology; Washington, 108(3), 374. 


\section{Tables and Figures}

Table 1: Differences Between Schools in the Analytic sample and the Inference Populations In Terms of Benchmarks Obtained from the CCD (Common Core of Data, AY 2015-2016) and OCR (Office of Civil Rights, AY 2015-2016.

\begin{tabular}{|c|c|c|c|c|c|c|c|c|c|c|c|c|c|c|c|}
\hline & \multicolumn{5}{|c|}{$\begin{array}{l}\text { Inference Population } \\
\left(\text { All }=11,221 \text { Schools }^{ \pm}\right)\end{array}$} & \multicolumn{5}{|c|}{$\begin{array}{l}\text { Analytic sample (Weighted) } \\
\qquad\left(\text { All = } 76 \text { Schools }^{ \pm} \text {) }\right.\end{array}$} & \multicolumn{5}{|c|}{$\begin{array}{c}\text { Comparisons } \\
\text { Mean Differences }\end{array}$} \\
\hline & $\begin{array}{c}\text { All } \\
\text { Mean }\end{array}$ & $\begin{array}{c}\text { Bottom } \\
75 \% \\
\text { Mean } \\
\end{array}$ & $\begin{array}{c}\text { Top } \\
25 \% \\
\text { Mean } \\
\end{array}$ & $\begin{array}{c}\text { Low } \\
\text { Minority } \\
\text { Mean } \\
\end{array}$ & $\begin{array}{c}\text { High } \\
\text { Minority } \\
\text { Mean } \\
\end{array}$ & $\begin{array}{c}\text { All } \\
\text { Mean }\end{array}$ & $\begin{array}{c}\text { Bottom } \\
75 \% \\
\text { Mean }\end{array}$ & $\begin{array}{c}\text { Top } \\
25 \% \\
\text { Mean } \\
\end{array}$ & $\begin{array}{c}\text { Low } \\
\text { Minority } \\
\text { Mean }\end{array}$ & $\begin{array}{c}\text { High } \\
\text { Minority } \\
\text { Mean }\end{array}$ & All & $\begin{array}{c}\text { Bottom } \\
75 \%\end{array}$ & $\begin{array}{l}\text { Top } \\
25 \%\end{array}$ & $\begin{array}{l}\text { Low } \\
\text { Minority }\end{array}$ & $\begin{array}{l}\text { High } \\
\text { Minority }\end{array}$ \\
\hline $\begin{array}{l}\text { School-level } \\
\text { Chharacteristics } \\
\text { (9-th Graders) }\end{array}$ & & & & & & & & & & & & & & & \\
\hline $\begin{array}{l}\text { Proportion of } \\
\text { Female } \\
\text { Students }\end{array}$ & 0.48 & 0.48 & 0.49 & 0.48 & 0.48 & 0.50 & 0.49 & 0.51 & 0.51 & 0.47 & -0.02 & -0.01 & -0.02 & -0.03 & 0.01 \\
\hline $\begin{array}{l}\text { Proportion of } \\
\text { Asian Students }\end{array}$ & 0.04 & 0.03 & 0.07 & 0.03 & 0.05 & 0.02 & 0.01 & 0.06 & 0.02 & 0.03 & 0.02 & 0.02 & 0.01 & 0.01 & 0.02 \\
\hline $\begin{array}{l}\text { Proportion of } \\
\text { Black Students }\end{array}$ & 0.14 & 0.17 & 0.05 & 0.05 & 0.27 & 0.16 & 0.19 & 0.05 & 0.05 & 0.39 & -0.02 & -0.02 & 0 & 0 & -0.12 \\
\hline $\begin{array}{l}\text { Proportion of } \\
\text { Hispanic } \\
\text { Students }\end{array}$ & 0.21 & 0.24 & 0.10 & 0.10 & 0.36 & 0.19 & 0.20 & 0.13 & 0.18 & 0.21 & 0.02 & 0.04 & -0.03 & -0.08 & 0.15 \\
\hline
\end{tabular}




\begin{tabular}{|c|c|c|c|c|c|c|c|c|c|c|c|c|c|c|c|}
\hline $\begin{array}{l}\text { Proportion of } \\
\text { White Students }\end{array}$ & 0.57 & 0.51 & 0.74 & 0.77 & 0.29 & 0.58 & 0.55 & 0.72 & 0.71 & 0.33 & -0.01 & -0.04 & 0.02 & 0.06 & -0.04 \\
\hline $\begin{array}{l}\text { Proportion of } \\
\text { Other Race } \\
\text { Students }\end{array}$ & 0.05 & 0.05 & 0.04 & 0.05 & 0.04 & 0.05 & 0.05 & 0.04 & 0.05 & 0.04 & 0 & 0 & 0 & 0 & 0 \\
\hline $\begin{array}{l}\text { Total } \\
\text { Enrollment }\end{array}$ & 285 & 273 & 319 & 224 & 371 & 297 & 246 & 502 & 244 & 401 & -0.03 & 0.14 & -0.52 & 0.11 & 0.13 \\
\hline $\begin{array}{l}\text { Other School- } \\
\text { Level } \\
\text { Benchmarks }\end{array}$ & & & & & & & & & & & & & & & \\
\hline $\begin{array}{l}\text { Proportion of } \\
\text { Students } \\
\text { Enrolled in } \\
\text { Algebra } 1\end{array}$ & 0.22 & 0.24 & 0.19 & 0.21 & 0.24 & 0.22 & 0.23 & 0.20 & 0.20 & 0.27 & 0 & 0.01 & -0.01 & 0.01 & -0.03 \\
\hline $\begin{array}{l}\text { Proportion of } \\
\text { Students } \\
\text { Enrolled in } \\
\text { Algebra } 2\end{array}$ & 0.20 & 0.20 & 0.21 & 0.20 & 0.21 & 0.21 & 0.21 & 0.21 & 0.20 & 0.23 & -0.01 & -0.01 & 0 & 0 & -0.02 \\
\hline $\begin{array}{l}\text { Proportion of } \\
\text { Students } \\
\text { Enrolled in at } \\
\text { least one AP } \\
\text { course }\end{array}$ & 0.19 & 0.17 & 0.25 & 0.19 & 0.20 & 0.20 & 0.16 & 0.31 & 0.21 & 0.19 & -0.01 & 0.01 & -0.06 & -0.02 & 0.01 \\
\hline $\begin{array}{l}\text { Proportion of } \\
\text { Students who } \\
\text { took at least } 1 \\
\text { AP Exam }\end{array}$ & 0.70 & 0.68 & 0.75 & 0.70 & 0.71 & 0.68 & 0.67 & 0.71 & 0.68 & 0.69 & 0.02 & 0.01 & 0.04 & 0.02 & 0.02 \\
\hline
\end{tabular}




\begin{tabular}{|c|c|c|c|c|c|c|c|c|c|c|c|c|c|c|c|}
\hline $\begin{array}{l}\text { Proportion of } \\
\text { Students who } \\
\text { did not take } \\
\text { any AP Exam }\end{array}$ & 0.29 & 0.30 & 0.24 & 0.28 & 0.29 & 0.34 & 0.33 & 0.34 & 0.31 & 0.38 & |-0.05 & -0.03 & -0.1 & -0.03 & -0.09 \\
\hline $\begin{array}{l}\text { Proportion of } \\
\text { Students Who } \\
\text { Passed at least } \\
1 \text { AP Exam }\end{array}$ & 0.41 & 0.31 & 0.66 & 0.45 & 0.36 & 0.36 & 0.25 & 0.64 & 0.44 & 0.21 & 0.05 & 0.06 & 0.02 & 0.01 & 0.15 \\
\hline $\begin{array}{l}\text { Proportion of } \\
\text { Students who } \\
\text { did not Pass } \\
\text { any AP Exam }\end{array}$ & 0.35 & 0.42 & 0.19 & 0.26 & 0.48 & 0.42 & 0.48 & 0.25 & 0.33 & 0.58 & -0.07 & -0.06 & -0.06 & -0.07 & -0.1 \\
\hline $\begin{array}{l}\text { Proportion of } \\
\text { Students who } \\
\text { are Chronically } \\
\text { Absent }\end{array}$ & 0.21 & 0.23 & 0.15 & 0.19 & 0.24 & 0.20 & 0.21 & 0.18 & 0.17 & 0.25 & 0.01 & 0.02 & -0.03 & 0.02 & -0.01 \\
\hline $\begin{array}{l}\text { Generalizability } \\
\text { Index } \\
\text { (Including all } \\
\text { covariates } \\
\text { above in the } \\
\text { sampling } \\
\text { propensity } \\
\text { score model) }\end{array}$ & & & & & & & & & & & .94 & .94 & .90 & .95 & .88 \\
\hline
\end{tabular}

Notes. All data were obtained from the same sources and were not estimated from student-level data. ${ }^{ \pm} \mathrm{A}$ small number of schools do not have information available from the CCD and/or CRDC. Those schools are excluded from the mean calculations as appropriate. The last panel shows mean differences-standardized mean differences (SMD) for all non-proportion-based covariates and absolute differences for proportion-based covariates. 
Table 3: Differences Between the School Districts in the Analytic sample and the Inference Populations When Using District-level Benchmarks Obtained from CCD (Common Core of Data, AY 2015-2016), SDDS (School District Demographics System, 2006 to 2010), and ACS (American Community Survey, 2006 to 2010)

\begin{tabular}{|c|c|c|c|c|c|}
\hline \multirow[t]{2}{*}{ District-Level Covariates } & \multicolumn{2}{|c|}{$\begin{array}{c}\text { Inference Population } \\
\text { (7,111 Unique School } \\
\text { Districts) }\end{array}$} & \multicolumn{2}{|c|}{$\begin{array}{c}\text { Analytic sample } \\
\text { (58 Unique School } \\
\text { Districts) }\end{array}$} & \multirow{2}{*}{$\begin{array}{c}\text { Comparisons } \\
\text { Mean } \\
\text { Differences }\end{array}$} \\
\hline & Mean & $S D$ & Mean & $S D$ & \\
\hline Proportion of Female Students in District & 0.49 & 0.03 & 0.49 & 0.03 & 0 \\
\hline Proportion of Black Students in District & 0.09 & 0.17 & 0.11 & 0.19 & -0.02 \\
\hline Proportion of Hispanic Students in District & 0.15 & 0.21 & 0.17 & 0.20 & -0.02 \\
\hline Proportion of Asian Students in District & 0.03 & 0.05 & 0.02 & 0.03 & 0.01 \\
\hline Proportion of White Students in District & 0.69 & 0.28 & 0.64 & 0.27 & 0.04 \\
\hline Proportion of English Language Learners in District & 0.04 & 0.07 & 0.05 & 0.07 & -0.01 \\
\hline Proportion of Special Education Students in District & 0.14 & 0.04 & 0.14 & 0.03 & 0 \\
\hline Proportion of Free Lunch Students in District & 0.42 & 0.23 & 0.41 & 0.19 & 0.01 \\
\hline Total Per-pupil Expenditure & $\$ 12,338$ & $\$ 3,835$ & $\$ 12,133$ & $\$ 3,640$ & 0.05 \\
\hline Proportion of Adults with BA Degree or higher & 0.25 & 0.15 & 0.27 & 0.12 & -0.02 \\
\hline Proportion of Households with 5-17-year-old in poverty & 0.15 & 0.10 & 0.14 & 0.08 & 0.01 \\
\hline Proportion of Households headed by Single Mother & 0.23 & 0.10 & 0.24 & 0.11 & -0.01 \\
\hline $\begin{array}{l}\text { Proportion of Households receiving Food stamps or SNAP } \\
\text { benefits }\end{array}$ & 0.16 & 0.11 & 0.15 & 0.09 & 0.01 \\
\hline Percentage Unemployed & 0.05 & 0.02 & 0.04 & 0.02 & 0.01 \\
\hline
\end{tabular}




\begin{tabular}{|c|c|c|c|c|c|}
\hline Proportion of 15-19-year old giving birth & 0.03 & 0.04 & 0.02 & 0.02 & 0.01 \\
\hline Income at the $50^{\text {th }}$ Percentile & $\$ 62,931$ & $\$ 26,031$ & $\$ 61,848$ & $\$ 22,157$ & 0.04 \\
\hline Proportion of $25-64-$ Year-Old Males in Labor Force & 0.83 & 0.10 & 0.85 & 0.07 & -0.02 \\
\hline Proportion of 25-64-Year-Old Females in Labor Force & 0.72 & 0.08 & 0.73 & 0.07 & -0.01 \\
\hline $\begin{array}{l}\text { Total Number of 5-17-Year-Old Children enrolled in Public } \\
\text { Schools in the District }\end{array}$ & 3,394 & 9,554 & 11,249 & 23,787 & -0.83 \\
\hline
\end{tabular}

Notes. All data were obtained from the same sources and were not estimated from student-level data. ${ }^{ \pm} \mathrm{A}$ small number of districts do not have information available from the CCD and/or SDDS/ACS. Those districts are excluded from the mean calculation. The last panel shows mean differences-standardized mean differences for all non-proportion-based covariates and absolute differences for proportion-based covariates. 
Table 4: Generalizability Index - Comparisons of NSLM Analytic Sample to National Sample

\begin{tabular}{|l|c|c|c|}
\hline \multicolumn{1}{|c|}{ Inference Population } & $\begin{array}{c}\text { Number of Schools in } \\
\text { Corresponding Inference } \\
\text { Populations with non-missing } \\
\text { Covariates Used in Sampling } \\
\text { Propensity Score Model }\end{array}$ & $\begin{array}{c}\text { Number of Schools in Analytic } \\
\text { sample of NSLM with non- } \\
\text { missing Covariates Used in } \\
\text { Sampling Propensity Score } \\
\text { Model }\end{array}$ & Generalizability index \\
\hline All Public High Schools in the US & 9505 & 69 & .98 \\
\hline $\begin{array}{l}\text { All Public High Schools in the } \\
\text { Bottom 75\% of latent School } \\
\text { Achievement }\end{array}$ & 7177 & 50 & .97 \\
\hline $\begin{array}{l}\text { All Public High Schools in the Top } \\
\begin{array}{l}25 \% \text { of latent School } \\
\text { Achievement }\end{array}\end{array} \quad 2328$ & 19 & .93 \\
\hline $\begin{array}{l}\text { Schools with Low Minority } \\
\text { Concentration }\end{array}$ & 5745 & 41 & .98 \\
\hline $\begin{array}{l}\text { Schools with High Minority } \\
\text { Concentration }\end{array}$ & 3760 & 28 & .96 \\
\hline
\end{tabular}

Notes: The full NSLM sample includes 76 schools. For each population of inference, the schools in the population of inference were compared to those in the analytic sample of the NSLM based on racial composition (\%African American, \%Hispanic, \%White), socioeconomic composition (\%Free/Reduced-Price Lunch Recipients), gender composition (\%Male), the number of students in the school, the proportion of students in the district that are English Language Learners, and the proportion of Special Education students in the district. 
Table 5: Data Source for All Covariates Used

Data Source

\section{School District-level Covariates}

Proportion of Black Students in District

Proportion of Hispanic Students in District

Proportion of Asian Students in District

Proportion of White Students in District

Proportion of Special Education Students in District

Proportion of Free Lunch Students in District

Total Per-pupil Expenditure

Proportion of Adults with BA Degree or higher

Proportion of Households with 5-17-year-old in poverty

Proportion of Households headed by Single Mother

Proportion of Households receiving Food stamps or SNAP benefits

Percentage Unemployed

Proportion of 15-19-year old giving birth

Income at the 50th Percentile

Proportion of 25-64-Year-Old Males in Labor Force

Proportion of 25-64-Year-Old Females in Labor Force

SEDA (Curated from ACS/SDDS)

SEDA (Curated from ACS/SDDS)

SEDA (Curated from ACS/SDDS)

SEDA (Curated from ACS/SDDS)

SEDA (Curated from ACS/SDDS)

SEDA (Curated from ACS/SDDS)

SEDA (Curated from ACS/SDDS)

SEDA (Curated from ACS/SDDS)

SEDA (Curated from ACS/SDDS)

SEDA (Curated from ACS/SDDS)

SEDA (Curated from ACS/SDDS)

SEDA (Curated from ACS/SDDS)

SEDA (Curated from ACS/SDDS)

SEDA (Curated from ACS/SDDS)

SEDA (Curated from ACS/SDDS)

SEDA (Curated from ACS/SDDS)

\section{School-Level Covariates}

Percentage Male Students in School

Percentage Female Students in School

CCD

Proportion of Black Students in School

Proportion of Hispanic Students in School

CCD

Proportion of Asian Students in School

CCD

Proportion of Free and/or Reduced-Price Lunch Students in School

Proportion of $9^{\text {th }}$ Grade Male Students in School

CCD

Proportion of $9^{\text {th }}$ Grade Female Students in School

CCD

Proportion of $9^{\text {th }}$ Grade Black Students in School

CCD

Proportion of $9^{\text {th }}$ Grade Hispanic Students in School

CCD

Proportion of $9^{\text {th }}$ Grade Asian Students in School

CCD

Proportion of Students Enrolled in Algebra 1

CCD

Proportion of Students Enrolled in Algebra 2

OCR-CRDC

Proportion of Students Enrolled in at least one AP course 
Proportion of Students who took at least 1 AP Exam

OCR-CRDC

Proportion of Students who did not take any AP Exam

Proportion of Students Who Passed at least 1 AP Exam

OCR-CRDC

Proportion of Students who did not Pass any AP Exam

OCR-CRDC

Proportion of Students Enrolled in IB

OCR-CRDC

Proportion of Students who are Chronically Absent 


\section{Appendix}

\section{Table A1: Benchmarks from OCR}

The in-depth calculation used to create the benchmarks from the OCR are as shown below:

\begin{tabular}{|c|c|}
\hline & $\begin{array}{l}\text { Variables from OCR used in Author's Calculations (All variables taken } \\
\text { from AY 2015-16 OCR Data) }\end{array}$ \\
\hline $\begin{array}{l}\text { Proportion of Students } \\
\text { Enrolled in Algebra } 1\end{array}$ & $\frac{\text { Total number of students enrolled in Algebra } 1 \text { in school }}{\text { Total number of students enrolled in school }}$ \\
\hline $\begin{array}{l}\text { Proportion of Students } \\
\text { Enrolled in Algebra } 2\end{array}$ & $\frac{\text { Total number of students enrolled in Algebra } 2 \text { in school }}{\text { Total number of students enrolled in school }}$ \\
\hline $\begin{array}{l}\text { Proportion of Students } \\
\text { Enrolled in at least one AP } \\
\text { course }\end{array}$ & $\frac{\text { Total number of students enrolled in at least } 1 \text { AP Exam in school }}{\text { Total number of students enrolled in school }}$ \\
\hline $\begin{array}{l}\text { Proportion of Students who } \\
\text { took at least } 1 \text { AP Exam }\end{array}$ & $\frac{\text { Total number of students who took at least } 1 \text { AP Exam in school }}{\text { Total number of students enrolled in at least } 1 \text { AP course in school }}$ \\
\hline $\begin{array}{l}\text { Proportion of Students who did } \\
\text { not take any AP Exam }\end{array}$ & $\frac{\text { Total number of students who did not take any AP Exam in school }}{\text { Total number of students enrolled in at least } 1 \text { AP course in school }}$ \\
\hline $\begin{array}{l}\text { Proportion of Students Who } \\
\text { Passed at least } 1 \text { AP Exam }\end{array}$ & $\frac{\text { Total number of students who passed at least } 1 \text { AP Exam in school }}{\text { Total number of students who took at least } 1 \text { AP Exam in school }}$ \\
\hline $\begin{array}{l}\text { Proportion of Students who did } \\
\text { not Pass any AP Exam }\end{array}$ & $\frac{\text { Total number of students who did not pass any AP Exam in school }}{\text { Total number of students who took at least } 1 \text { AP Exam in school }}$ \\
\hline $\begin{array}{l}\text { Proportion of Students } \\
\text { Enrolled in IB }\end{array}$ & $\frac{\text { Total number of students enrolled in IB in school }}{\text { Total number of students enrolled in school }}$ \\
\hline $\begin{array}{l}\text { Proportion of Students who } \\
\text { are Chronically Absent }\end{array}$ & $\frac{\text { Total number of students who were chronically absent }}{\text { Total number of students enrolled in school }}$ \\
\hline
\end{tabular}


Table A2: Differences Between Schools in the Analytic sample and the Inference Population in Terms of Benchmarks Obtained from the CCD (Common Core of Data, AY 2015-2016) and OCR (Office of Civil Rights, AY 2015-2016), for the Sample Overall and for the Sampling Strata Used in Analysis.

\begin{tabular}{|c|c|c|c|c|c|c|c|c|c|c|}
\hline & \multicolumn{5}{|c|}{$\begin{array}{l}\text { Inference Population } \\
\text { (All =11,221 Schools) }\end{array}$} & \multicolumn{5}{|c|}{$\begin{array}{c}\text { Analytic sample (Unweighted) } \\
\text { (All = } 76 \text { Schools) }\end{array}$} \\
\hline & $\begin{array}{c}\text { All } \\
\text { Mean }\end{array}$ & $\begin{array}{l}\text { Bottom } \\
75 \% \\
\text { Mean }\end{array}$ & $\begin{array}{c}\text { Top } \\
25 \% \\
\text { Mean }\end{array}$ & $\begin{array}{c}\text { Low } \\
\text { Minority } \\
\text { Mean }\end{array}$ & $\begin{array}{l}\text { High } \\
\text { Minority } \\
\text { Mean }\end{array}$ & $\begin{array}{c}\text { All } \\
\text { Mean }\end{array}$ & $\begin{array}{c}\text { Bottom } \\
75 \% \\
\text { Mean }\end{array}$ & $\begin{array}{l}\text { Top } \\
25 \% \\
\text { Mean }\end{array}$ & $\begin{array}{l}\text { Low } \\
\text { Minority } \\
\text { Mean }\end{array}$ & $\begin{array}{c}\text { High } \\
\text { Minority } \\
\text { Mean }\end{array}$ \\
\hline \multicolumn{11}{|l|}{$\begin{array}{l}\text { School-level } \\
\text { Chharacteristics (9- } \\
\text { th Graders) }\end{array}$} \\
\hline $\begin{array}{l}\text { Proportion of Male } \\
\text { Students }\end{array}$ & 0.52 & 0.52 & 0.51 & 0.52 & 0.52 & 0.51 & 0.51 & 0.50 & 0.50 & 0.51 \\
\hline $\begin{array}{l}\text { Proportion of } \\
\text { Female }\end{array}$ & 0.48 & 0.48 & 0.49 & 0.48 & 0.48 & 0.49 & 0.49 & 0.50 & 0.50 & 0.49 \\
\hline $\begin{array}{l}\text { Proportion of Asian } \\
\text { students }\end{array}$ & 0.04 & 0.03 & 0.07 & 0.03 & 0.05 & 0.02 & 0.02 & 0.04 & 0.01 & 0.03 \\
\hline $\begin{array}{l}\text { Proportion of Black } \\
\text { Students }\end{array}$ & 0.14 & 0.17 & 0.05 & 0.05 & 0.27 & 0.15 & 0.18 & 0.07 & 0.06 & 0.27 \\
\hline $\begin{array}{l}\text { Proportion of } \\
\text { Hispanic Students }\end{array}$ & 0.21 & 0.24 & 0.10 & 0.10 & 0.36 & 0.18 & 0.18 & 0.16 & 0.09 & 0.29 \\
\hline $\begin{array}{l}\text { Proportion of White } \\
\text { Students }\end{array}$ & 0.57 & 0.51 & 0.74 & 0.77 & 0.29 & 0.60 & 0.57 & 0.68 & 0.78 & 0.36 \\
\hline $\begin{array}{l}\text { Proportion of Other } \\
\text { Race Students }\end{array}$ & 0.05 & 0.05 & 0.04 & 0.05 & 0.04 & 0.06 & 0.06 & 0.05 & 0.06 & 0.05 \\
\hline Total Enrollment & 285 & 273 & 319 & 224 & 371 & 291 & 243 & 426 & 206 & 401 \\
\hline
\end{tabular}




\begin{tabular}{|c|c|c|c|c|c|c|c|c|c|c|}
\hline $\begin{array}{l}\text { Proportion of } \\
\text { Students Enrolled } \\
\text { in Algebra } 1\end{array}$ & 0.22 & 0.24 & 0.19 & 0.21 & 0.24 & 0.23 & 0.24 & 0.19 & 0.21 & 0.25 \\
\hline $\begin{array}{l}\text { Proportion of } \\
\text { Students Enrolled } \\
\text { in Algebra } 2\end{array}$ & 0.20 & 0.20 & 0.21 & 0.20 & 0.21 & 0.19 & 0.19 & 0.21 & 0.18 & 0.21 \\
\hline $\begin{array}{l}\text { Proportion of } \\
\text { Students Enrolled } \\
\text { in at least one AP } \\
\text { course }\end{array}$ & 0.19 & 0.17 & 0.25 & 0.19 & 0.20 & 0.20 & 0.16 & 0.27 & 0.17 & 0.23 \\
\hline $\begin{array}{l}\text { Proportion of } \\
\text { Students who took } \\
\text { at least } 1 \text { AP Exam }\end{array}$ & 0.70 & 0.68 & 0.75 & 0.70 & 0.71 & 0.70 & 0.68 & 0.74 & 0.70 & 0.70 \\
\hline $\begin{array}{l}\text { Proportion of } \\
\text { Students who did } \\
\text { not take any AP } \\
\text { Exam }\end{array}$ & 0.29 & 0.30 & 0.24 & 0.28 & 0.29 & 0.31 & 0.34 & 0.24 & 0.30 & 0.33 \\
\hline $\begin{array}{l}\text { Proportion of } \\
\text { Students Who }\end{array}$ & & & & & & & & & & \\
\hline $\begin{array}{l}\text { Passed at least } 1 \\
\text { AP Exam }\end{array}$ & 0.41 & 0.31 & 0.66 & 0.45 & 0.36 & 0.38 & 0.24 & 0.65 & 0.35 & 0.41 \\
\hline $\begin{array}{l}\text { Proportion of } \\
\text { Students who did } \\
\text { not Pass any AP } \\
\text { Exam }\end{array}$ & 0.35 & 0.42 & 0.19 & 0.26 & 0.48 & 0.33 & 0.37 & 0.26 & 0.28 & 0.40 \\
\hline $\begin{array}{l}\text { Proportion of } \\
\text { Students Enrolled } \\
\text { in IB }\end{array}$ & 0.12 & 0.11 & 0.13 & 0.11 & 0.12 & 0.11 & 0.14 & 0.09 & 0.07 & 0.13 \\
\hline $\begin{array}{l}\text { Proportion of } \\
\text { Students who are } \\
\text { Chronically Absent }\end{array}$ & 0.21 & 0.23 & 0.15 & 0.19 & 0.24 & 0.20 & 0.22 & 0.15 & 0.20 & 0.20 \\
\hline
\end{tabular}


Notes. All data were obtained from the same sources and were not estimated from student-level data. ${ }^{ \pm} \mathrm{A}$ small number of schools do not have information available from the CCD and/or CRDC. Those schools are excluded from the mean calculation. Asterisks denote significance at the $0.1 \%\left({ }^{* * *}\right), 1 \%\left({ }^{* *}\right)$, and $5 \%\left(^{*}\right)$ levels. 
Table A3: Differences Between the School Districts in the Analytic sample and the Inference Populations When Using Similar Benchmarks to Stuart et al. (2017)

\begin{tabular}{|c|c|c|c|c|c|}
\hline \multirow[t]{2}{*}{ District-Level Covariates } & \multicolumn{2}{|c|}{$\begin{array}{l}\text { Inference Population } \\
\text { (7,111 Unique School } \\
\text { Districts) }\end{array}$} & \multicolumn{2}{|c|}{$\begin{array}{c}\text { Analytic sample } \\
\text { (58 Unique School Districts) }\end{array}$} & \multirow{2}{*}{$\begin{array}{c}\text { Comparisons } \\
\text { Difference }\end{array}$} \\
\hline & Mean & $S D$ & Mean & $S D$ & \\
\hline Number of Schools & 10.3 & 24.26 & 31.3 & 59.39 & -0.88 \\
\hline Number of Teachers & 360 & 937 & 1231 & 2506 & -0.94 \\
\hline Number of Students & 1,621 & 3,877 & 5,111 & 10,468 & -0.91 \\
\hline Total Per-pupil Expenditure & $\$ 12,338$ & 0.05 & $\$ 12,133$ & 0.03 & 0 \\
\hline Number of Students Per Teacher & 0.69 & 0.28 & 0.64 & 0.27 & -0.16 \\
\hline Proportion of Students who are non-white & 0.31 & 0.28 & 0.36 & 0.27 & -0.05 \\
\hline Proportion of English Language Learners & 0.04 & 0.07 & 0.05 & 0.07 & -0.01 \\
\hline Proportion of Students Eligible for Free/Reduced Price Lunch & 0.42 & 0.23 & 0.41 & 0.19 & 0.01 \\
\hline Proportion of Schools with School-Wide Title 1 & $\$ 12,338$ & $\$ 3,835$ & $\$ 12,133$ & $\$ 3,640$ & 0.05 \\
\hline Proportion of Schools Eligible for Title 1 & 0.25 & 0.15 & 0.27 & 0.12 & -0.02 \\
\hline State grade 4 NAEP Math scores & 241 & 4.62 & 241 & 4.26 & 0.08 \\
\hline State grade 4 NAEP Reading scores & 222 & 5.17 & 222 & 5.10 & 0.02 \\
\hline State grade 8 NAEP Math scores & 283 & 5.75 & 282 & 4.98 & 0.13 \\
\hline State grade 8 NAEP Reading scores & 265 & 4.45 & 265 & 4.16 & 0.09 \\
\hline Proportion Located in "City" & 0.08 & 0.27 & 0.22 & 0.42 & -0.14 \\
\hline Proportion Located in "Suburb" & 0.29 & 0.45 & 0.19 & 0.40 & 0.10 \\
\hline Proportion Located in "Town" & 0.25 & 0.43 & 0.29 & 0.46 & -0.04 \\
\hline
\end{tabular}




\begin{tabular}{|l|l|l|l|} 
Proportion Located in "Rural" & 0.37 & 0.29 & 0.48 \\
\hline $\begin{array}{l}\text { Generalizability Index (Including all covariates above in the } \\
\text { sampling propensity score model) }\end{array}$ & & & 0.08 \\
\hline
\end{tabular}

Notes. All data were obtained from the same sources and were not estimated from student-level data. ${ }^{ \pm} \mathrm{A}$ small number of districts do not have information available from the CCD. Those districts are excluded from the mean calculation. The last panel shows mean differencesstandardized mean differences for all non-proportion-based covariates and absolute differences for proportion-based covariates. 
Table A4: Absolute Standardized Mean Differences Between Schools in the Analytic sample and the Inference Population in Terms of Benchmarks Obtained from the CCD (Common Core of Data, AY 2015-2016) and OCR (Office of Civil Rights, AY 2015-2016), for the Sample Overall and for the Sampling Strata Used in Analysis.

\begin{tabular}{|c|c|c|c|c|c|c|c|c|c|c|c|c|c|c|c|}
\hline & \multicolumn{5}{|c|}{$\begin{array}{l}\text { Inference Population } \\
\left(\text { All }=11,221 \text { Schools }^{ \pm}\right)\end{array}$} & \multicolumn{5}{|c|}{$\begin{array}{l}\text { Analytic sample (Weighted) } \\
\qquad\left(\text { All }=76 \text { Schools }^{ \pm}\right)\end{array}$} & \multicolumn{5}{|c|}{$\begin{array}{c}\text { Comparisons } \\
\text { Absolute SMD in Parentheses }\end{array}$} \\
\hline & $\begin{array}{c}\text { All } \\
\text { Mean }\end{array}$ & $\begin{array}{c}\text { Bottom } \\
75 \% \\
\text { Mean }\end{array}$ & $\begin{array}{c}\text { Top } \\
25 \% \\
\text { Mean } \\
\end{array}$ & $\begin{array}{c}\text { Low } \\
\text { Minority } \\
\text { Mean }\end{array}$ & $\begin{array}{c}\text { High } \\
\text { Minority } \\
\text { Mean }\end{array}$ & $\begin{array}{c}\text { All } \\
\text { Mean }\end{array}$ & $\begin{array}{c}\text { Bottom } \\
75 \% \\
\text { Mean }\end{array}$ & $\begin{array}{c}\text { Top } \\
25 \% \\
\text { Mean }\end{array}$ & $\begin{array}{c}\text { Low } \\
\text { Minority } \\
\text { Mean }\end{array}$ & $\begin{array}{c}\text { High } \\
\text { Minority } \\
\text { Mean }\end{array}$ & All & $\begin{array}{l}\text { Bottom } \\
75 \%\end{array}$ & $\begin{array}{l}\text { Top } \\
25 \%\end{array}$ & $\begin{array}{l}\text { Low } \\
\text { Minority }\end{array}$ & $\begin{array}{l}\text { High } \\
\text { Minority }\end{array}$ \\
\hline $\begin{array}{l}\text { Proportion of } \\
\text { Female } \\
\text { Students }\end{array}$ & 0.48 & 0.48 & 0.49 & 0.48 & 0.48 & 0.50 & 0.49 & 0.51 & 0.51 & 0.47 & $(0.13$ & $(0.15)$ & 0.09 & $(0.21)$ & $(0.07)$ \\
\hline $\begin{array}{l}\text { Proportion of } \\
\text { Asian Students }\end{array}$ & 0.04 & 0.03 & 0.07 & 0.03 & 0.05 & 0.02 & 0.01 & 0.06 & 0.02 & 0.03 & $(0.19)$ & $(0.19)$ & $(0.23)$ & $(0.22)$ & $(0.16)$ \\
\hline $\begin{array}{l}\text { Proportion of } \\
\text { Black Students }\end{array}$ & 0.14 & 0.17 & 0.05 & 0.05 & 0.27 & 0.16 & 0.19 & 0.05 & 0.05 & 0.39 & $(0.05)$ & $(0.04)$ & $(0.19)$ & $(0.10)$ & $(0.01)$ \\
\hline $\begin{array}{l}\text { Proportion of } \\
\text { Hispanic } \\
\text { Students }\end{array}$ & 0.21 & 0.24 & 0.10 & 0.10 & 0.36 & 0.19 & 0.20 & 0.13 & 0.18 & 0.21 & $(0.12)$ & $(0.22)$ & $(0.48)$ & $(0.05)$ & $(0.27)$ \\
\hline $\begin{array}{l}\text { Proportion of } \\
\text { White Students }\end{array}$ & 0.57 & 0.51 & 0.74 & 0.77 & 0.29 & 0.58 & 0.55 & 0.72 & 0.71 & 0.33 & $(0.08)$ & $(0.16)$ & $(0.29)$ & $(0.03)$ & $(0.36)$ \\
\hline $\begin{array}{l}\text { Proportion of } \\
\text { Other Race } \\
\text { Students }\end{array}$ & 0.05 & 0.05 & 0.04 & 0.05 & 0.04 & 0.05 & 0.05 & 0.04 & 0.05 & 0.04 & $(0.09)$ & $(0.08)$ & $(0.26)$ & $(0.07)$ & $(0.24)$ \\
\hline $\begin{array}{l}\text { Total } \\
\text { Enrollment }\end{array}$ & 285 & 273 & 319 & 224 & 371 & 297 & 246 & 502 & 244 & 401 & $(0.03)$ & $(0.14)$ & $(0.52)$ & $(0.11)$ & $(0.13)$ \\
\hline
\end{tabular}




\begin{tabular}{|c|c|c|c|c|c|c|c|c|c|c|c|c|c|c|c|}
\hline $\begin{array}{l}\text { Other School- } \\
\text { Level } \\
\text { Benchmarks }\end{array}$ & & & & & & & & & & & & & & & \\
\hline $\begin{array}{l}\text { Proportion of } \\
\text { Students } \\
\text { Enrolled in } \\
\text { Algebra } 1\end{array}$ & 0.22 & 0.24 & 0.19 & 0.21 & 0.24 & 0.22 & 0.23 & 0.20 & 0.20 & 0.27 & $(0.04)$ & $(0.04)$ & $(0.09)$ & $(0.03)$ & $(0.13)$ \\
\hline $\begin{array}{l}\text { Proportion of } \\
\text { Students } \\
\text { Enrolled in } \\
\text { Algebra } 2\end{array}$ & 0.20 & 0.20 & 0.21 & 0.20 & 0.21 & 0.21 & 0.21 & 0.21 & 0.20 & 0.23 & $(0.12)$ & $(0.17)$ & $(0.02)$ & $(0.28)$ & $(0.13)$ \\
\hline $\begin{array}{l}\text { Proportion of } \\
\text { Students } \\
\text { Enrolled in at } \\
\text { least one AP } \\
\text { course }\end{array}$ & 0.19 & 0.17 & 0.25 & 0.19 & 0.20 & 0.20 & 0.16 & 0.31 & 0.21 & 0.19 & $(0.06)$ & $(0.02)$ & $(0.10)$ & $(0.12)$ & $(0.27)$ \\
\hline $\begin{array}{l}\text { Proportion of } \\
\text { Students who } \\
\text { took at least } 1 \\
\text { AP Exam }\end{array}$ & 0.70 & 0.68 & 0.75 & 0.70 & 0.71 & 0.68 & 0.67 & 0.71 & 0.68 & 0.69 & $(0.01)$ & $(0.01)$ & $(0.04)$ & (0) & $(0.01)$ \\
\hline $\begin{array}{l}\text { Proportion of } \\
\text { Students who } \\
\text { did not take } \\
\text { any AP Exam }\end{array}$ & 0.29 & 0.30 & 0.24 & 0.28 & 0.29 & 0.34 & 0.33 & 0.34 & 0.31 & 0.38 & $(0.09)$ & $(0.13)$ & $(0.02)$ & $(0.04)$ & $(0.14)$ \\
\hline $\begin{array}{l}\text { Proportion of } \\
\text { Students Who } \\
\text { Passed at least } \\
1 \text { AP Exam }\end{array}$ & 0.41 & 0.31 & 0.66 & 0.45 & 0.36 & 0.36 & 0.25 & 0.64 & 0.44 & 0.21 & $(0.08)$ & $(0.18)$ & $(0.02)$ & $(0.19)$ & $(0.13)$ \\
\hline $\begin{array}{l}\text { Proportion of } \\
\text { Students who } \\
\text { did not Pass } \\
\text { any AP Exam }\end{array}$ & 0.35 & 0.42 & 0.19 & 0.26 & 0.48 & 0.42 & 0.48 & 0.25 & 0.33 & 0.58 & $(0.05)$ & $(0.11)$ & $(0.22)$ & $(0.06)$ & $(0.23)$ \\
\hline $\begin{array}{l}\text { Proportion of } \\
\text { Students who }\end{array}$ & 0.21 & 0.23 & 0.15 & 0.19 & 0.24 & 0.20 & 0.21 & 0.18 & 0.17 & 0.25 & $(0.06)$ & $(0.07)$ & $(0.01)$ & $(0.06)$ & $(0.22)$ \\
\hline
\end{tabular}


are Chronically

Absent

Notes. All data were obtained from the same sources and were not estimated from student-level data. ${ }^{ \pm} \mathrm{A}$ small number of schools do not have information available from the CCD and/or CRDC. Those schools are excluded from the mean calculations as appropriate. The last panel shows absolute standardized mean differences. 
Table A5: Absolute Standardized Mean Differences Between the School Districts in the Analytic sample and the Inference Populations When Using District-level Benchmarks Obtained from CCD (Common Core of Data, AY 2015-2016), SDDS (School District Demographics System, 2006 to 2010), and ACS (American Community Survey, 2006 to 2010)

\begin{tabular}{|c|c|c|c|c|c|}
\hline \multirow[t]{2}{*}{ District-Level Covariates } & \multicolumn{2}{|c|}{$\begin{array}{c}\text { Inference Population } \\
\text { (7,111 Unique School } \\
\text { Districts) }\end{array}$} & \multicolumn{2}{|c|}{$\begin{array}{c}\text { Analytic sample } \\
\text { (58 Unique School } \\
\text { Districts) }\end{array}$} & \multirow{2}{*}{$\begin{array}{c}\text { Comparisons } \\
\text { Absolute } \\
\text { SMD }\end{array}$} \\
\hline & Mean & $S D$ & Mean & $S D$ & \\
\hline Proportion of Female Students in District & 0.49 & 0.03 & 0.49 & 0.03 & 0 \\
\hline Proportion of Black Students in District & 0.09 & 0.17 & 0.11 & 0.19 & 0.12 \\
\hline Proportion of Hispanic Students in District & 0.15 & 0.21 & 0.17 & 0.20 & 0.10 \\
\hline Proportion of Asian Students in District & 0.03 & 0.05 & 0.02 & 0.03 & 0.20 \\
\hline Proportion of White Students in District & 0.69 & 0.28 & 0.64 & 0.27 & 0.18 \\
\hline Proportion of English Language Learners in District & 0.04 & 0.07 & 0.05 & 0.07 & 0.14 \\
\hline Proportion of Special Education Students in District & 0.14 & 0.04 & 0.14 & 0.03 & 0 \\
\hline Proportion of Free Lunch Students in District & 0.42 & 0.23 & 0.41 & 0.19 & 0.04 \\
\hline Total Per-pupil Expenditure & $\$ 12,338$ & $\$ 3,835$ & $\$ 12,133$ & $\$ 3,640$ & 0.05 \\
\hline Proportion of Adults with BA Degree or higher & 0.25 & 0.15 & 0.27 & 0.12 & 0.13 \\
\hline Proportion of Households with 5-17-year-old in poverty & 0.15 & 0.10 & 0.14 & 0.08 & 0.10 \\
\hline Proportion of Households headed by Single Mother & 0.23 & 0.10 & 0.24 & 0.11 & 0.10 \\
\hline $\begin{array}{l}\text { Proportion of Households receiving Food stamps or SNAP } \\
\text { benefits }\end{array}$ & 0.16 & 0.11 & 0.15 & 0.09 & 0.09 \\
\hline Percentage Unemployed & 0.05 & 0.02 & 0.04 & 0.02 & 0.5 \\
\hline
\end{tabular}


Proportion of 15-19-year old giving birth

Income at the $50^{\text {th }}$ Percentile

Proportion of 25-64-Year-Old Males in Labor Force

Proportion of 25-64-Year-Old Females in Labor Force

Total Number of 5-17-Year-Old Children enrolled in Public Schools in the District

\begin{tabular}{cc|cc|c|}
0.03 & 0.04 & 0.02 & 0.02 & 0.25 \\
$\$ 62,931$ & $\$ 26,031$ & $\$ 61,848$ & $\$ 22,157$ & 0.04 \\
0.83 & 0.10 & 0.85 & 0.07 & 0.20 \\
0.72 & 0.08 & 0.73 & 0.07 & 0.13 \\
& & & & \\
3,394 & 9,554 & 11,249 & 23,787 & 0.81 \\
\hline
\end{tabular}

Notes. All data were obtained from the same sources and were not estimated from student-level data. ${ }^{ \pm} \mathrm{A}$ small number of districts do not have information available from the CCD and/or SDDS/ACS. Those districts are excluded from the mean calculation. The last panel shows mean absolute standardized mean differences. 
Table A6: Generalizability Index - Rules of Thumb for Interpretations

\begin{tabular}{|l|l|}
\hline Generalizability Index Magnitude & $\begin{array}{l}\text { Rules of thumb Interpretations } \\
\text { (Tipton, 2014, p. 491) }\end{array}$ \\
\hline Greater than .90 & "Very High" Generalizability \\
\hline $.80-.90$ & "High" Generalizability \\
\hline $.50-.80$ & "Medium" Generalizability \\
\hline Less than .50 & "Low" Generalizability \\
\hline
\end{tabular}

For smaller samples (30-40 sites), using simulations Tipton (2014) shows that the above table can be used as a rough guide to interpret the generalizability of the experimental sample. For larger experimental samples, (Tipton et al., 2017), interpretation should be based on comparisons with random samples and the sampling distribution (that follows a $\chi^{2}$ distribution) based on the number of observable benchmarks that are being used for comparisons as well as the experimental sample size (see Tipton, Hallberg, Hedges, \& Chan, 2017 for further guidance). 


\section{R Code used to generate Generalizabillity index (Reproduced from Tipton, 2014 Online Supplement)}

The following code takes as inputs two vectors (e.g. the propensity scores/logits), dat1B and dat2B, and outputs the value of the generalizabillity index. The propensity scores of the experimental sample and population inference are calculated from logistic regression models (code not shown) independently as described in the method section in the main text, prior to their use as inputs in the below code.

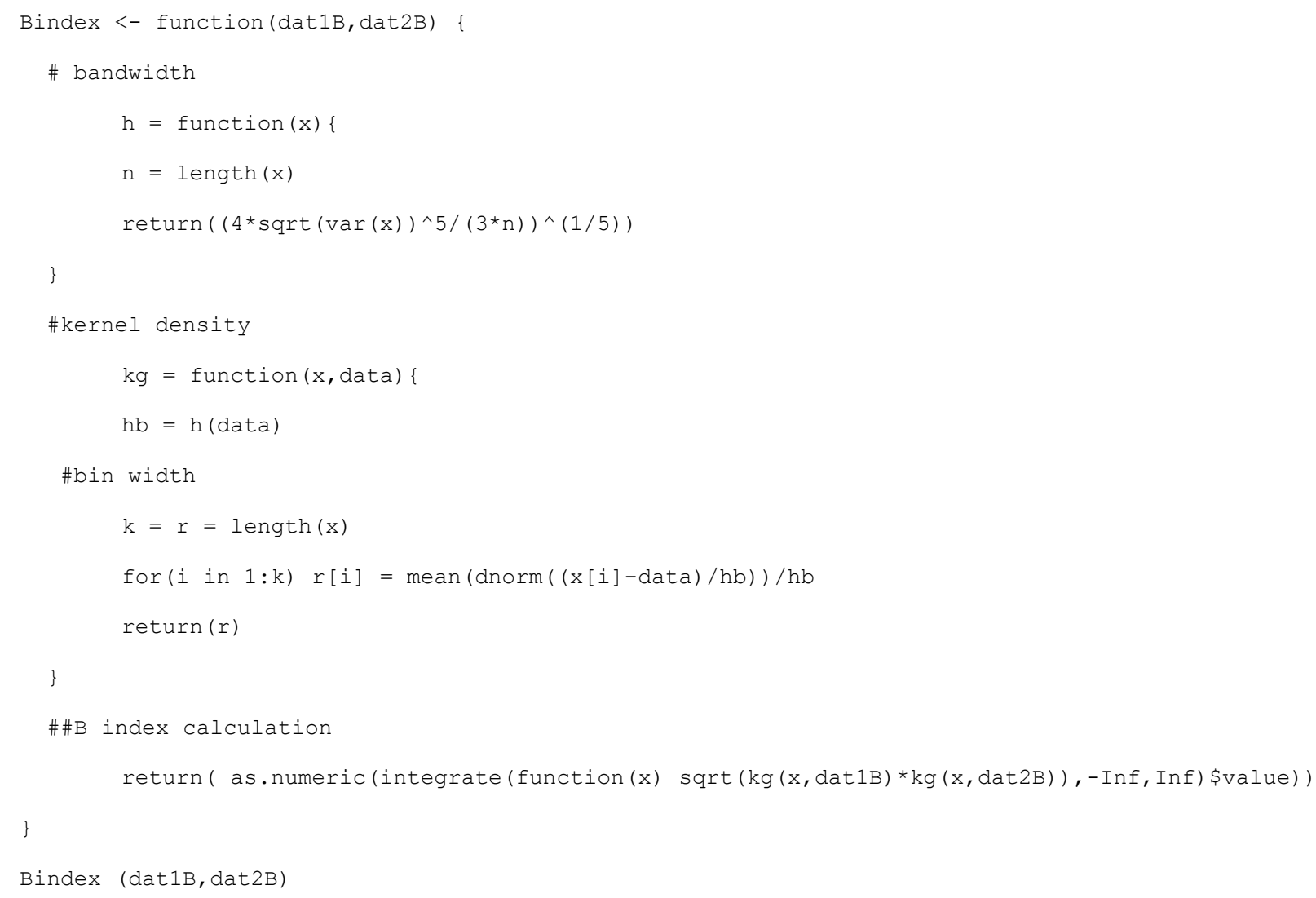

